\title{
Systematics of Rhithrocloeninae with new species from Uganda
}

\section{Систематика Rhithrocloeninae с описание новых видов из Уганды}

\author{
Nikita J. Kluge \\ Н.Ю. КАюге
}

Department of Entomology, St. Petersburg State University, Universitetskaya nab., 7/9, St. Petersburg 199034, Russia. E-mail: kluge@FK13889.spb.edu. Website: http://www.insecta.bio.pu.ru

Кафедра энтомологии, биолого-почвенный факультет, С.-Петербургский государственный университет, Университетская наб., $7 /$ 8, С.-Петербург 199034, Россия.

KEY WORDS: systematics, Ephemeroptera, Baetidae, Protopatellata, Rhithrocloeon, Kivuiops, Bugilliesia, new species.

КЛЮЧЕВЫЕ СЛОВА: систематика, Ephemeroptera, Baetidae, Protopatellata, Rhithrocloeon, Kivuiops, Bugilliesia, новые виды.

ABSTRACT. The new subfamily Rhithrocloeoninae is described. The taxon Rhithrocloeoninae (or Rhithrocloeon/fg1) includes a plesiomorphon Bugilliesia and a holophyletic taxon Rhithrocloeon/fg2, which is divided into Rhithrocloeon/fg3 and Kivuiops. Rhithrocloeon (Kivuiops) insuetum, Rh. (K.) munyagae sp.n. and Rh. $(K$.$) elgonensis sp.n. are described as imagoes and$ subimagoes reared from larvae in Uganda. Comments on some species of Rhithrocloeon/fg3 and Bugilliesia from Uganda, Tanzania, Mali and Sudan are given.

РЕЗЮМЕ. Описывается новое подсемейство Rhithrocloeoninae. Таксон Rhithrocloeoninae (или Rhithrocloeon/fg1) включает плезиоморфон Bugilliesia и голофилетический таксон Rhithrocloeon/fg2, который подразделяется на Rhithrocloeon/fg3 и Kivuiops. По имаго и субимаго, выведенным из личинок, описываются Rhithrocloeon (Kivuiops) insuetum, Rh. (K.) munyagae sp.n. и Rh. $(K$.$) elgonensis sp.n. из Уганды.$ Приведены замечания о некоторых видах Rhithrocloeon/fg3 и Bugilliesia из Уганды, Танзании, Мали и Судана.

\section{Introduction}

All Baetidae s.str., or Turbanoculata Kluge, 1997, are divided into a plesiomorphon Protopatellata Kluge \& Novikova, 2011 and a holophyletic taxon Anteropatellata Kluge, 1997. The taxon Protopatellata is characterized by retaining the same primitive position of patella-tibial suture, which occurs in most Ephemeroptera: in all stages of both sexes this suture is developed on middle and hind legs, but absent on fore legs; in selected taxa patella-tibial suture is reduced on all legs, but it never appears on fore legs. The taxon Anteropatellata is characterized by an autapomorphy: patella-tibial suture is restored on fore legs, which become similar to middle and hind legs; only in male subimago and imago fore legs lack patella-tibial suture (see Table 1).
Table 1. Presence of patella-tibial suture in Protopatellata and Anteropatellata. Таблица 1. Наличие пателло-тибиального шва у Protopatellata и Anteropatellata

\begin{tabular}{|c|c|c|c|c|c|c|c|}
\hline & \multicolumn{3}{|c|}{ male } & \multicolumn{3}{|c|}{ female } \\
\hline & & 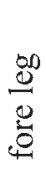 & 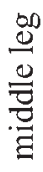 & $\frac{0}{\varrho}$ & $\frac{\infty}{\stackrel{\infty}{0}}$ & 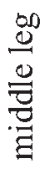 & 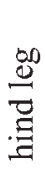 \\
\hline \multirow{3}{*}{$\begin{array}{l}\text { plesiomorphon } \\
\text { Protopatellata }\end{array}$} & larva & - & + & + & - & + & + \\
\hline & subimago & - & + & + & - & + & + \\
\hline & imago & - & + & + & - & + & + \\
\hline \multirow{3}{*}{ Anteropatellata } & larva & + & + & + & + & + & + \\
\hline & subimago & - & + & + & + & + & + \\
\hline & imago & - & + & + & + & + & + \\
\hline
\end{tabular}

The plesiomorphon Protopatellata is distributed mainly in Ethiopian Region, a few species are distributed in Asia and America [Kluge, 2011]. Among others, to this plesiomorphon belongs a holophyletic taxon Rhithrocloeon/fg1 described here; its distribution is limited by Ethiopian Region.

Here are used principles of cladoendesis [Kluge \& Novikova, 2011; Kluge, in press] and rank-free hierarchical nomenclature [Kluge, 2004]. Morphological terms used here, are explained in the previous paper [Kluge \& Novikova, 2011]. All material, including holotypes and paratypes of new species, is permanently deposited in the Zoological Institute of Russian Academy of Sciences (Saint Petersburg, Russia); temporarily locates in the Department of Entomology of Saint Petersburg State University. In the lists of material examined, the following arbitrary signs are used: L-S-I $\sigma^{\top}$ - male imago reared from larva, with larval and subimaginal exuviae; $\mathbf{L}-\mathbf{S} / \mathbf{I} \sigma^{\top}$ - male imago extracted from subimago reared from larva, with larval exuviae; $\mathbf{L} / \mathbf{S} \circlearrowleft^{7}$ - male subimago 
extracted from mature larva; L-S-I ${ }_{+}$- female imago reared from larva, with larval and subimaginal exuviae.

Taxa discussed here form the following classification:

1. Rhithrocloeon/fg1

1.1. Rhithrocloeon/fg2

1.1.1. Rhithrocloeon/fg3

1.1.1-1. Rhithrocloeon/fg3 sp.1

1.1.1-2. Rhithrocloeon/fg3 sp.2

1.1.2. Kivuiops/g(1), or Kivuiops

1.1.2-1. Kivuiops/g(1) insuetum [Cloeon]

1.1.2-2. Kivuiops/g(1) elouardi [Rhithrocloeon]

1.1.2-3. Kivuiops/g(1) munyagae sp.n. [Rhithrocloeon]

1.1.2-4. Kivuiops/g(1) elgonensis sp.n. [Rhithrocloeon]

1.2. Plesiomorphon Bugilliesia/g(1), or Bugilliesia

1.2-1. Bugilliesia/g(1) sp.N

1.2-2. Bugilliesia/g(1) sp.K

1.2-3. Bugilliesia/g(1) biloba [Bugilliesia]

1.2-4. Bugilliesia/g(1) notabile [Centroptilum]

1.2-5. Bugilliesia/g(1) sudanense [Centroptilum]

1.2-6. Bugilliesia/g(1) griseum [Afroptilum]

\section{System of Rhithrocloeon/fg1 \\ 1. Rhithrocloeon/fg1 \\ Figs 1-46.}

Systematic position: pm.Protopatellata-Rhithrocloeon/fg1.

Hierarchical typified name: Rhithrocloeon/fg1 (incl. Bugilliesia) [f: Rhithrocloeoninae Kluge, subfam. n., type genus Rhithrocloeon; g: Rhithrocloeon Gillies, 1985, type species Cloeon permirum Kopelke, 1980 (design. orig.)].

Possible rank-based names:

— subfam. Rhithrocloeoninae;

- tribe Rhithrocloeonini;

- gen. Rhithrocloeon s.1.

In circumscription fits:

- Bugilliesia complex: Gillies, 2001:32; Gattolliat, 2003; 2006 (non Lugo-Ortiz \& McCafferty, 1996).

Autapomorphies.

(1) Male genitals have unique structure: distal segment of gonostylus is lost (see 1.1), larval protogonostyli are brought together (see 1.3).

(1.1) Structure of gonostylus (Figs 12-18, 31, 40-42). Gonostylus [which initially for Liberevenata has integral $1^{\text {st }}+2^{\text {nd }}$ segment and articulated $3^{\text {rd }}$ (distal) segment] is «ankylosed»: it lacks distal segment and consists of a single $1^{\text {st }}+2^{\text {nd }}$ segment of composite shape: its proximal part (initial $1^{\text {st }}$ segment) is strongly projected medially-ventrally; its distal part (initial $2^{\text {nd }}$ segment) has inner side either straight (Fig. 42), or soft (Fig. 15). Unlike Rhithrocloeon/fg1, in all other Liberevenata distal segment of gonostylus is retained; $2^{\text {nd }}$ segment is often arched medially, so that its inner side is concave.

(1.2.) Structure of penis (Figs 12-18, 31, 40, 42). Gonovectes are completely fused with penial bridge; gonoducts open at the middle of the integral penis. In other respects penis structure is variable: in some species it retains a form of integral sclerotized bridge, movably articulated with lateroapical angles of abdominal segment IX (Figs 12-18, 31, 45); in some species it is partly fused with protogonostyli to form a composite construction (Figs 40-42). Complete fusion of gonovectes with penial bridge, besides Rhirhtocloeon/fg1, independently occurs in Anteropatellata-Cloeon/fg1.

(1.3) Larval protogonostyli (Figs 1, 46). Male larva has protogonostyli brought together (unlike other Turbanoculata, whose protogonostyi are widely separated); in mature larva buds of subimaginal gonostyli, developed under larval cuticle, are entirely convergent, to that their apices are brought together. This character is known for three examined species of Kivuiops and for Bugilliesia/g(1) sudanense [Centroptilum . Unlike Rhithrocloeon/fg1, in all other Protopatellata, as well as in Anteropatellata-non-Baetovectata, buds of $2^{\text {nd }}$ segments of subimaginal gonostyli are divergent.

(2) Maxillary palp has $2^{\text {nd }}$ segment widened and flattened toward apex; $3^{\text {rd }}$ segment somewhat narrower, short and triangular, separated from $2^{\text {nd }}$ segment by oblique suture (Figs 27-28).

Characters of unclear phylogenetic status.

(3) Maxilla of «Cloeon-type», i.e. its three canines and distal dentiseta are pointed and bent to the same direction (Fig. 27).

(4) Larval legs of «Cloeon-type», i.e. slender, with femora parallel-sided (Fig. 5); claws slender, slightly arched, denticles on inner side small or absent. Claw either retains both rows of denticles (in plesiomorphon Bugilliesia), or has one row [see below, Rhithrocloeon/fg2 (2)].

(5) Tergalii able to rhythmic respiratory movements. This was observed by me for all examined species of Kivuiops/ $\mathrm{g}(1)$ and reported by Gillies [1997] for one species of Bugilliesia/g(1) - griseum [Afroptilum]. Judging by the same paper [Gillies, 1997: Table 1], Rhithrocloeon/fg3 has immobile tergalii; but this conclusion was based on observation of a single individual of Rhithrocloeon sp., and can be an error.

(6) Hind wings, if present, of «Centroptilum-type»: narrow, with two longitudinal veins, with simple (not bipointed) hooked costal process (Fig. 43). Hind wings are retained in plesiomorphon Bugilliesia, but absent in Rhithrocloeon/fg2.

(7) In subimago of both sexes all segments of all tarsi are covered by pointed microlepides. This is true for species examined (see below). The same in all other examined Protopatellata, Anteropatellata-non-Baetovectata and some Baetovectata (unlike some Baetovectata, which have blunt microlepides).

Plesiomorphies. In all stages of both sexes patella-tibial suture is present on middle and hind legs, being absent on fore leg (as characteristic for the plesiomorphon Protopatellata - Table 1) (Figs 5, 6). Fore wing with one marginal intercalary in each space (Fig. 21) (unlike Baetovectata).

Composition. Rhithrocloeon/fg1 includes the following taxa: (1) holophyletic taxon Rhithrocloeon/fg2; (2) plesiomorphon Bugilliesia/g(1); (3) Mutelocloeon Gillies \& Elouard, 1990 with type species bihoumi Gillies \& Elouard, 1990 [Mutelocloeon] and presumably attributed corbeti Kimmins, 1956 [Centroptilum]; (4) Adnoptilum Gattolliat \& Monaghan, 2010 with two species - type species ottkei Gattolliat \& Monaghan, 2010 [Adnoptilum] and thomasorum Lugo-Ortiz \& McCafferty, 1997 [Mutelocloeon]. Redescriptions of Rhithrocloeon/fg2 and Bugilliesia/g(1) are given below. The taxa Mutelocloeon and Adnoptilum have been described basing on non-reared material, so their diagnoses are not reliable enough; both have hind wings reduced, and in this respect differ from Bugilliesia/g(1) [Gillies \& Elouard, 1990; Gattolliat \& Monaghan, 2010].

\subsection{Rhithrocloeon/fg2 (Figs 1-37)}

Systematic position: pm.Protopatellata-Rhithrocloeon/fg1Rhithrocloeon/fg2.

Hierarchical typified name: Rhithrocloeon/fg2 (sine Bugilliesia; incl. Kivuiops).

Possible rank-based names:

- gen. Rhithrocloeon;

- subgen. Rhithrocloeon.

In circumscription fits:

— gen. Rhithrocloeon: Gillies, 1985.

Autapomorphies.

(1) Apical setae of paraglossa are shifted to ventral side, so that apical margin is free from setae (Fig. 10) (unique 
apomorphy); apical setae always form 3 regular rows. Shape of labium is characteristic and identical in all species: paraglossa is widened apically; labial palp has $2^{\text {nd }}$ segment bluntly projected medially (unlike sharply projected in Bugilliesia).

(2) Larval claw [slender - see Rhithrocloeon/fg1 (4)] has one row of denticles (Fig. 7) (instead of initial two rows). The same in some other taxa of Protopatellata and in Anteropatellata-Baetungulata.

(3) Hind wings absent; larva has no vestiges of hind protoptera (non-unique apomorphy).

Characters of unclear phylogenetic status.

(4) Each tergalius I-VII [able to respiratory movement see Rhithrocloeon/fg1 (5)] is bordered by integral marginal rib, whose whole distal part (including apex of tergalius) bears a regular row of small oblique seta-bearing denticles. The same in many other taxa, but not in Bugilliesia, whose tergalii have apex soft and non-denticulate. In Rhithrocloeon/ fg2 shape of tergalii individually varies from oval to lanceolate, symmetric or slightly asymmetric [Gillies, 1988: Figs 40-42].

Composition. Rhithrocloeon/fg2 is divided into Rhithrocloeon/fg3 and a Kivuips/g1.

\subsubsection{Rhithrocloeon/fg3}

Figs 11, 24, 37.

Systematic position: pm.Protopatellata-Rhithrocloeon/fg1Rhithrocloeon/fg2 - Rhithrocloeon/fg3.

Hierarchical typified name: Rhithrocloeon/fg3 (sine Kivuiops).

Possible rank-based names:

- gen. Rhithrocloeon;

- subgen. Rhithrocloeon in gen. Rhithrocloeon.

In circumscription fits:

— gen. Rhithrocloeon: Lugo-Ortiz \& McCafferty, 1996.

\section{Autapomorphy.}

(1) Prostheca of right mandible slender, seta-like, without denticles [Gillies, 1988: Figs 34, 36] (unlike prostheca of left mandible, which is wide and dentate, as in all Rhithrocloeon/fg1). This differs both from Kivuiops (whose right prostheca is widened) and from Bugilliesia (whose right prostheca is plesiomorphically moderately narrow and dentate [Gillies, 1990: Figs 71-73]).

Character of unclear phylogenetic status.

(2) Labrum has uniform structure in both species: widened distally, with median incision small; in the specimen examined, dorsal surface with one pair of latero-distal setae and a pair of submedian setae (Fig. 24).

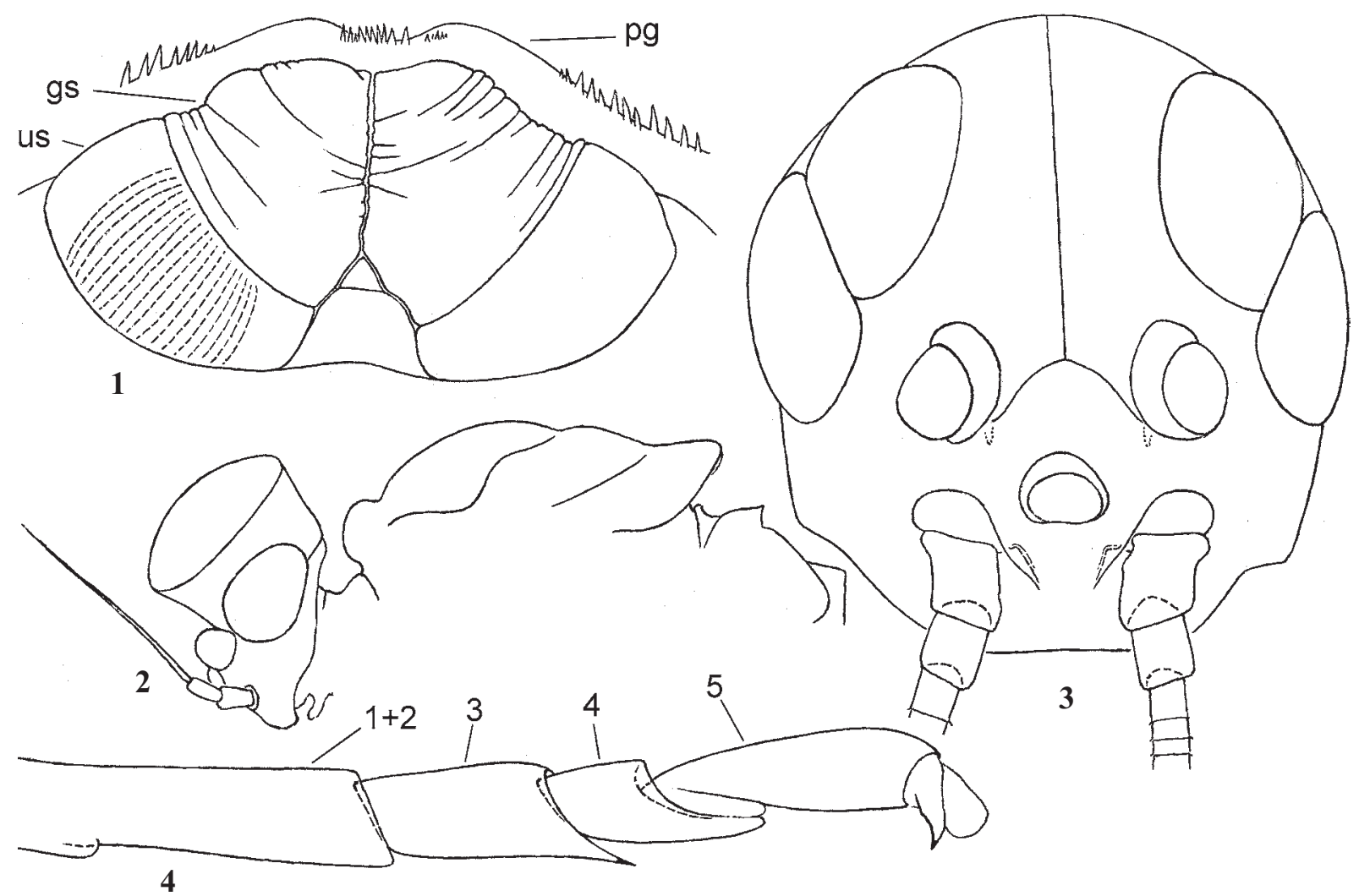

Figs 1-4. Rhithrocloeon/fg2-Kivuiops/g1 insuetum [Cloeon]: 1 - posterior margin of IX abdominal sternum (protogonostyli) of mature male larva and buds of subimaginal genitals folded under larval cuticle (left gonostylar muscle shown by interruptede lines); 2 - male imaginal head and notum; 3 - had of male larva, front view; 4 - tarsus of imaginal middle leg; gs — subimaginal gonostylus; pg - larval protogonostylus; us - subimaginal unistyliger; $1+2$ - fused $1^{\text {st }}$ and $2^{\text {nd }}$ tarsomeres.

Рис. 1-4. Rhithrocloeon/fg2-Kivuiops/g1 insuetum [Cloeon]: 1 - задний край IX стернит брюшка (протогоностили) зрелой личинки самца и зачатки субимагинальных гониталий, смятые под личиночной кутикулой (левая гоностилярная мышца показана прерывистыми линиями); 2 - голова и нотум самца имаго; 3 - голова личинки самца, вид спереди; 4 - лапка средней ноги имаго. gs - субимагинальный гоностиль; pg — личиночный протогоностиль; us - субимагинальный унистилигер; 1+2 — слитые 1-й и 2й тарсомеры. 
Plesiomorphy.

(3) Unlike Kivuiops, maxilla [of «Cloeon-type» - see Rhithrocloeon/fg1 (3)] retains more than one seta in innerdorsal row.

Composition. Rhithrocloeon/fg3 includes 2 species: permirum Kopelke, 1980 [Cloeon] and indicator Gillies,
1985 [Rhithrocloeon]. For both species imagoes were reared from nymphs; male imagoes have different shape of gonostyli, but for larvae "specific identification is presently not possoible" [Gillies, 1988: 56]. Two larval specimens are examined.

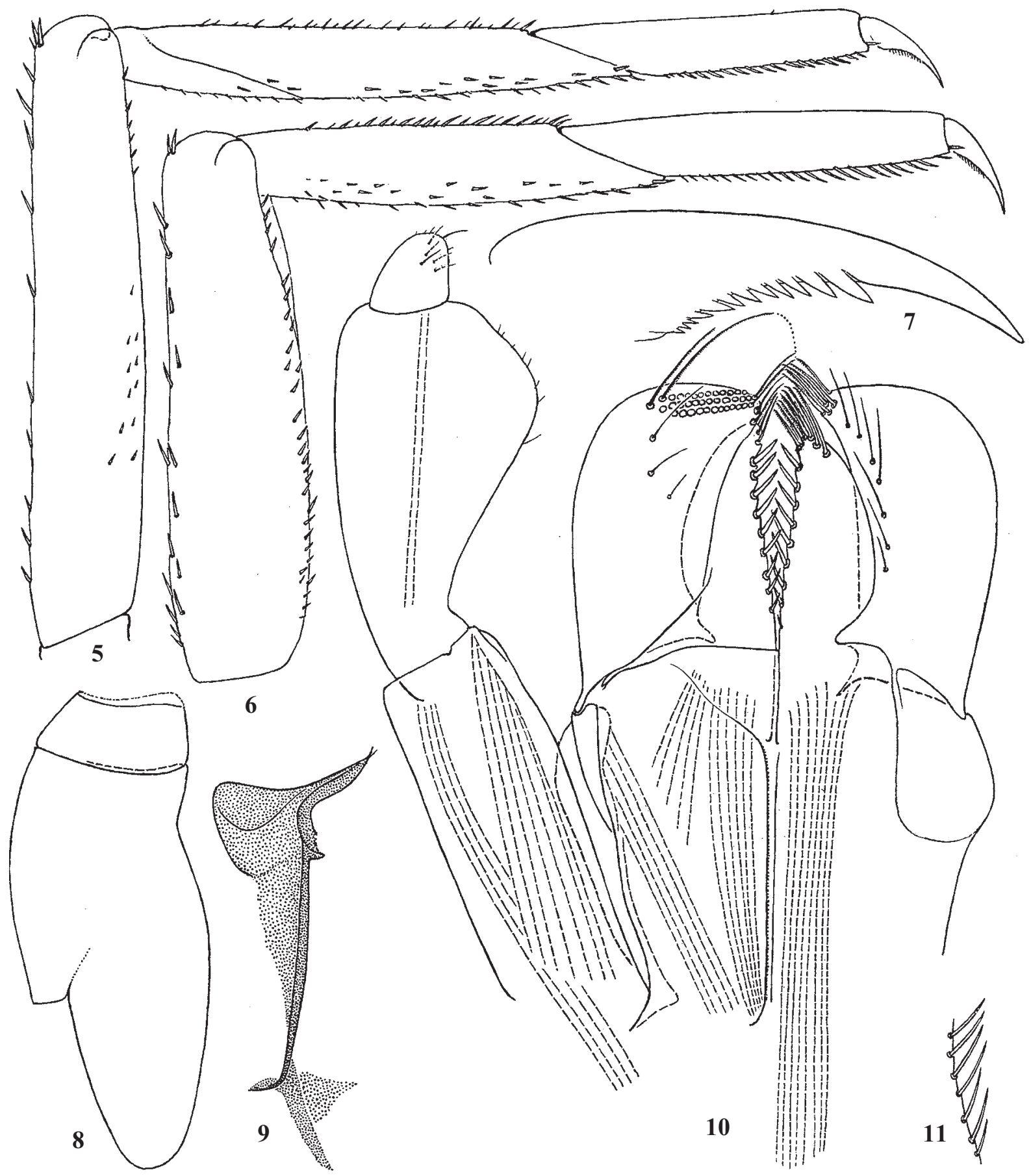

Figs 5-11. Rhithrocloeon/fg2: 5-10 — Rhithrocloeon/fg2-Kivuiops/g1 insuetum [Cloeon]; 11 - Rhithrocloeon/fg3 sp.1; 5 — larval hind leg (anterior side); 6 - larval fore leg (the same); 7 - claw; 8 - exuviae of right half of larval pronotum and mesonotum; 9 subimaginal exuviae of left postsubalar sclerite and lateropostnotal crest; 10 — labim (in left — ventral view, in right — dorsal view, muscles shown by interrupted lines); 11 - setae on inner margin of glossa.

Рис. 5-11. Rhithrocloeon/fg2: 5-10 — Rhithrocloeon/fg2-Kivuiops/g1 insuetum [Cloeon]; 11 — Rhithrocloeon/fg3 sp.1; 5 — задняя нога личинки (передня сторона); 6 - передняя нога личинки (то же); 7 - коготок; 8 - экзувий правой половины пронотума и мезонотума личинки; 9 - субимагинальный экзувий левого постсубалярного склерита и латеропостнотального гребня; 10 - нижняя губа (слева вентрально, справа дорсально, мышцы показаны прерывистыми линиями); 11 - щетинки на внутреннем крае глоссы. 


\subsection{1-1. Rhithrocloeon/fg3 sp. 1}

Figs 11, 24.

REFERENCES. Rhithrocloeon sp.: Gillies, 1988: 56 (larva). MATERIAL. TANZANIA, river Sigi, Amani, 4.III.1985, coll. M.T. Gillies: larval mouthparts on slide (No. B409).

\subsection{1-2. Rhithrocloeon/fg3 sp. 2}

Fig. 37.

MATERIAL. UGANDA, Rwenzori mountains, Kasese district, stream in forest - tributary of river Mubuku above Ruboni, 8.VIII.2007, N. Kuge: 1 immature larva.

Larva. Head narrower than in Kivuiops, antennae brought together, frons between them forms a longitudinal kiel. Mandibles with incisor+kinetodontium more slender than in Kivuiops, right prostheca slender [as in Gillies, 1988: Figs 33-36]. Caudalii unicolor, without dark band (unlike Kivuiops).

\subsubsection{Kivuiops/g(1), or Kivuiops}

Figs 1-10, 12-23, 25-36.

Systematic position: pm.Protopatellata-Rhithrocloeon/fg1Rhithrocloeon/fg2-Kivuiops/g(1).

Hierarchical typified name: Kivuiops/g(1) [g: Kivuiops LugoOrtiz \& McCafferty 2007, type species Cloeon insuetum Kopelke 1980 (design. orig.; objective synonyms: Kivua McCafferty \& LugoOrtiz (in Lugo-Ortiz \& McCafferty, 1996) (non Kivua Forsius, 1934); Novokivua Özdikmen, 2008).

Possible rank-based names:

- subgen. Kivuiops in gen. Rhithrocloeon

- gen. Kivuiops.

In circumscription fits:

— gen. Kivua: Lugo-Ortiz \& McCafferty, 1996;

- gen. Kivuiops: Lugo-Ortiz \& McCafferty, 2007;

— gen. Novokivua: Özdikmen, 2008.

Autapomorphies.

(1) Prostheca of right mandible widened, stout and dentate, similar to prostheca of left mandible (Fig. 30). This differs both from Rhithrocloeon/fg3 (whose right prostheca is seta-like [Gillies, 1988: Figs 34, 36]) and from Bugilliesia (whose right prostheca is plesiomorphically narrow and dentate [Gillies, 1990: Figs 71-73]).

(2) On maxilla [of «Cloeon-type» — see Rhithrocloeon/ fg1 (3)], inner-dorsal row of setae (which represents continuation of the row of dentisetae) consists of a single stout seta, which is especially long (much longer than dentisetae) and bent proximally (Fig. 27); rarely one smaller seta locates proximad to it. Unlike Kivuips, in Rhithrocloeon/fg 3 and Bugilliesia the inner-dorsal row retains several setae, which are not so long and not bent proximally.

(3) On labium [modified — see Rhithrocloeon/fg2 (1)] setae on inner side of glossae are short and stout (Fig. 10) (unlike Rhithrocloeon/fg3, whose setae are longer and thinner - Fig. 11).

(4) Larval paraproct has numerous small fine denticles, directed perpendicular to its margin (Fig. 36) (unlike Rhithrocloeon/fg3, whose paraproct has fewer oblique denticles - Fig. 37)

\section{Characters of unclear phylogenetic status.}

(5) On cuticle of subimaginal wing each microtrichion arises from center of a large brown round spot on colorless background (Fig. 22). Examined species of Bugilliesia have no such spots. Subimagoes of Rhithrocloeon/fg3 are not described, so it is unclear, if this apomorphy belongs to Kivuiops/g(1), or to Rhithrocloeon/fg2 in general.

(6) All species have similar shape of gonostyli (Figs 12$18,20,31)$, different from gonostyli of each two species of Rhithrocloeon/fg3. Possibly, plesiomorphy.
Composition. Kivuiops/g(1) includes 4 species: insuetum Kopelke, 1980 [Cloeon]; elouardi Gillies, 1989 [Rhithrocloeon]; munyagae sp.n. [Rhithrocloeon (Kivuiops)]; and elgonensis sp.n. [Rhithrocloeon (Kivuiops)].

Comments. Lugo-Ortiz and McCafferty [1996] established the genus Kivua (later renamed to Kivuiops) and separated it from the genus Rhithrocloeon basing on a single character: in Kivuiops gonostylus apex is "blunt", while in Rhithrocloeon it is "pointed". Basing on this single character, these authors regarded Rhithrocloeon to be sister group of Bugilliesia, but not of Kivuiops. Actually, gonostylus of Rhithrocloeon/fg1 tends to be sclerotized along the whole outer side, being membranose at distal part of inner side (Fig. $15)$; in this case, in ventral or dorsal view it can look as "blunt" or "pointed" depending on fixation (Fig. 20).

\section{Key to Male imagoes of KIVUiOPS}

1(2) Middle and hind tarsus with two thorns: on $1^{\text {st }}+2^{\text {nd }}$ and $3^{\text {rd }}$ segments (Fig. 32). Median projection of penis has simple trapezoid shape, without finger-like process (Fig. 31) .... elgonensis sp.n. [Rhithrocloeon].

2(1) Middle and hind tarsus with one thorn, on $3^{\text {rd }}$ segment only (Fig. 4). Median projection of penis has composite shape, with a finger-like process (Figs 12, 20).

3(4) Wing widest in middle or distal half. West Africa. [Gillies, 1989: Fig. 1; Gattolliat, 2006: Fig. 20] eloaurdi [Rhithrocloeon].

4(3) Wing widest in proximal half (Fig. 21). East Africa.

5(6) Median projection of penis has trapezoid proximal part longer than finger-like process (Fig. 12) .... insuetum [Cloeon].

6(5) Median projection of penis has trapezoid proximal part shorter than finger-like process (Fig. 20)

\section{munyagae sp.n. [Rhithrocloeon].}

Key to LaRvae of KIVUIOPS Larvae of eloaurdi [Rhithrocloeon] unknown.

1(2) Posterior margin of metanotum in median part bears a regular row of dark stout pointed denticles (Fig. 23), which are much longer than denticles on $1^{\text {st }}$ abdominal tergum and similar to denticles on last abdominal terga ... insuetum [Cloeon] and munyagae sp.n. [Rhithrocloeon].

2(1) Posterior margin of metanotum in median part bears a few irregular small denticles (Fig. 25), which are not larger than vestigial denticles of $1^{\text {st }}$ abdominal tergum ..................... ........................... elgonensis sp.n. [Rhithrocloeon].

\subsection{2-1. Kivuiops/g(1) insuetum [Cloeon]} Figs 1-10, 12-18.

Systematic position: Rhithrocloeon/fg1-Rhithrocloeon/fg2Kivuiops/g(1).

Original binomen: Cloeon insuetum Kopelke, 1980.

Possible binomina:

- Rhithrocloeon (Kivuiops) insuetum;

- Kivuiops insuetum.

REFERENCES. Cloeon insuetum Kopelke, 1980 (male imago). Rhithrocloeon insuetum: Gillies, 1985; 1989. Kivua insueta: LugoOrtiz \& McCafferty, 1996; Gattolliat, 2006. Kivuiops insuetum: Lugo-Ortiz \& McCafferty, 2007. Novokivua insuetum: Özdikmen, 2008.

MATERIAL. UGANDA: Kasese district, Rwenzori mountains: basin of river Mubuku, Ruboni, 28.VII-6.VIII.2007, coll. N. Kluge: 2 L-S-IO', 1 L-S-Iㅇ, 3 larvae; Kilembe, 14-20.VIII.2007, coll. N. Kluge: 2 L-S-IO', 1 L-S $\sigma^{\top}, 4$ L-S-I + , 24 larvae.

Larva. Cuticular COLORATION: Cuticle of head and thorax brown with lighter blanks. Legs light, nearly unicolor; fore tarsus can be slightly darkened, for femur can have 

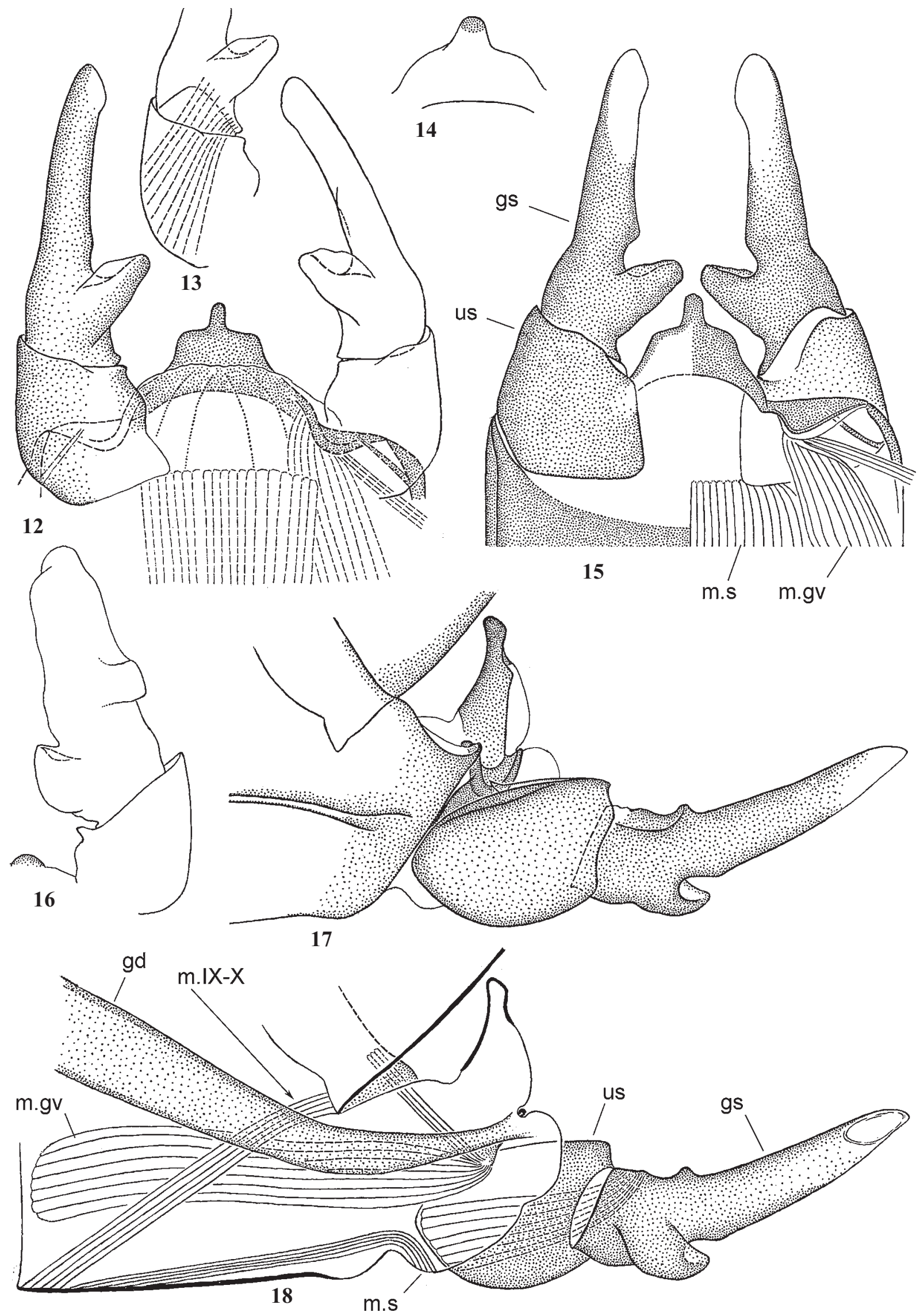
indistinct darkening. Abdominal terga I-IX nearly uniformly brown, laterally lighter; tergum IX sometimes with a pair of lighter round medioposterior sigilla. Abdominal sterna I-IX brown, somewhat lighter than terga, laterally lighter; small paired fields of dentate protuberances light. Abdominal segment X light. Caudalii have proximal parts light, middle parts dark brown, apices light; swimming setae brown.

HyPODERMAL COLORATION: Mature male larva has abdominal terga VII-IX darker than others, as in imago.

SHAPE AND SETATION: Frons between antennal bases rather narrow and elevated (Fig. 3). Labrum relatively long, narrowing distally, with median incision narrow and deep; dorsal surface with 2 pairs of latero-distal setae and a pair of submedian setae; ventral surface with a pair of long regular rows of stout setae along lateral margins; lateral setae absent (as in Fig. 26). Both mandibles with incisor and kinetodontium stout and fused, prosthecae widened [see Kivuiops (1)], with setae between prostheca and mola (as in Figs 29, 30). Maxilla as in Fig. 27 [see Rhithrocloeon/fg1 (3) and Kivuiops (2)]. Labium as in Fig. 10 [see Rhithrocloeon/fg2 (1) and Kivuiops (3)]. Pronotum relatively short, mesonotum strongly convex (Fig. 8). Tergum and pleura of metathorax partly covered by scales of the same structure as scales on abdomen (as in Fig. 33); a few such scales on episternum of mesothorax. Posterior margin of metanotum in median part bears a regular row of dark stout pointed denticles (as in Fig. 23); they are much longer than denticles on $1^{\text {st }}$ abdominal tergum and similar to denticles on last abdominal terga. Lateroposterior margins of metanotum smoothly rounded, without any vestiges of hind protoptera. Legs slender (Figs 5-6). Femora of fore and middle legs have subequal length, femur of hind leg longer; femur of fore leg thickest in proximal part, femora of middle and hind legs more slender and parallelsided. Tibia+tarsus of fore and middle legs have subequal length, tibia+tarsus of hind leg longer; on fore leg tibia and tarsus have subequal length, on middle and hind legs tibia longer than tarsus. Patella short, on fore legs not expressed. Outer margin of each femur with sparse short stout spine-like setae, not forming regular rows; apex of femur with two such setae. Inner margin of fore femur with many pointed spinelike setae; inner margin of middle and hind femora without them. Anterior side of fore femur without spine-like setae; anterior side of middle femur with many pointed spine-like setae; anterior side of hind femur with fewer pointed spinelike setae. Posterior side of all femora with a few smaller blunt spine-like setae near inner margin (not shown in Figs 56). Tibiae of all legs with irregularly situated pointed spinelike setae; spine-like setae on outer margin of each tibia numerous, occupy whole its length. Tarsi of all legs with a regular row of pointed spine-like setae and a fewer spine-like setae on posterior side near inner margin (not shown in Figs 5-6). Femora, tibiae and tarsi of all legs densely covered by scales similar to scales on metathorax and abdomen, but smaller. Claw slender, with a single row of small oblique denticles (Fig. 7). Abdomen without lateral or posterolateral spines. Abdominal tergum I medially deeply emarginate (as in Fig. 25). Abdominal terga and sterna covered by scales in wide nests with operculate corners, hind margins with regular pointed denticles (as in Fig. 33): tergum I with vestigial denticles; terga II-IX with well-developed denticles longest on posteriormost segments; tergum $\mathrm{X}$ with thinner pointed denticles of the same length. Sterna I-IV lack denticles; sternum V with vestigial denticles; sterna VI-VIII with welldeveloped denticles; sternum IX of female with similar denticles, of male as in Fig. 1, with protogonostyli brought together [see Rhithrocloeon/fg1 (1.3)]. Paraproct with numerous small denticles directed perpendicular to its margin (as in Fig. 36) [see Kivuiops (4)]. Tergalii able to make rhythmic respiratory movements. Tergalii of all 7 pairs elongate (length twice or more exceeds width), oval or lanceolate, either nearly symmetric or slightly asymmetric (costal margin more convex in distal part and/or anal margin more convex in proximal part), tergalii of middle pairs $1 \frac{1 / 4}{4}-1 \frac{1}{2}$ times larger than tergalii of first and last pairs. Each tergalius has entire margin armed with fine rib; its distal part, including extreme apex, bears small oblique seta-bearing denticles. Paracercus as long as cerci (with characteristic cuticular coloration see above). Primary swimming setae well developed on all segments of caudalii, except 1-5 apical segments. Posterior margin of each segment of caudalii bears a regular row of pointed denticles (similar to denticles on posterior margins of abdominal terga) and a regular row of contiguous scale nests close to it (each scale nest is twice smaller than scale nest of abdominal terga).

Subimago. Cuticular coloration: Cuticle of thorax brown; membranose areas of pleura ligh, sclerites brown; postsubalar sclerite as in Fig. 9. Mesonotum brown, medioparapsidal suture contrastingly light, other sutures (antelateroparapsidal, lateroparapsidal and others) dark brown. Wings look brown due to brown rings surrounding each microtrichion base (as in Fig. 22). Cuticle of legs light brownish, with darker maculae: fore femur with longitudinal macula at distal $1 / 3$ of posterior side; tibia of each leg with darkened base and apex; tibia of middle and hind leg with longitudinal macula at proximal $1 / 3$ of outer side. Cuticle of abdomen brown.

Hypodermal COLORATION: Male subimagi has abdominal terga VII-X dark, as in imago.

TEXTURE: All tarsi covered with pointed microlepides. Other body parts nearly entirely covered with dark microtrichia. imago.

About genital structure - see characteristics of male

Imago, male. Head, thorax and abdominal segment I entirely brown. Turban eyes dark red. Anteronotal protuberance prominent and rounded (Fig. 2). Mesoscitum strongly convex (Fig. 2), with median suture projected as a convex

Figs 12-18. Rhithrocloeon/fg2-Kivuiops/g1 insuetum [Cloeon], male genitals: 12 - genitals of imago, ventral view (sterno-styligeral muscle and right penial muscles shown by interrupted lines, gonoducts shown by dotted lines); 13 - left unistyliger and base of gonostylus (gonostylar muscle shown by interrupted lines); 14 - penis of subimago, extracted from mature larva; 15 - genitals of imago (in left ventral view, in right — dorsal view); 16 - subimaginal exuviae of penis and right unistyliger with gonostylus; 17 — genitals of imago, lateral view; 18 - the same, median section; $g d$ - gonoduct; gs — gonostylus; $\mathrm{m} . \mathrm{gv}$ - muscle of gonovectis; $\mathrm{m} . \mathrm{s}$ — median sterno-styligeral muscle; m.IX-X - intersegmental ventral muscle; us - unistyliger.

Рис. 12-18. Rhithrocloeon/fg2-Kivuiops/g1 insuetum [Cloeon], гениталии самца: 12 - гениталии имаго, вентрально (стерностилигеральные мышцы и правые мышцы пениса показаны прерывистыми линиями, гонодукты показаны пунктиром); 13 - левый унистилигер и основание гоностиля (гоностилярная мышца показана прерывистыми линиями); 14 - пенис субимаго, отпрепарирован из зрелой личинки; 15 - гениталии имаго (слева вентрально, справа дорсально); 16 - субимагинальный экзувий пениса и правого унистилигера с гоностилем; 17 — гениталии имаго, латерально; 18 - то же, медиальный срез; gd — гонодукт; gs — гоностиль; m.gv — мышца гоновектиса; m.s — медиальная стерно-стилигеральная мышца; m.IX-X—межсегментарная вентральная мышца; us — унистилигер. 
ridge. Fore wing widest in proximal part (as in Fig. 21) [Kopelke, 1980: Fig. 39]; veins brownish, costal brace and bases of Sc and R diffusively darkened. Legs light ocher. On middle and hind legs $1^{\text {st }}+2^{\text {nd }}$ tarsomere has no apical thorn, only $3^{\text {rd }}$ tarsomere has apical thorn (Fig. 4). Abdominal segments II-VI colorless, hind margins of each tergum narrowly lined by dark brown, lateral tracheal trunks bordered by brownish; terga VII-X brown, sterna VII-IX lighter brown. Unistyligers at most brown; gonostyli brown, distally colorless; penial sclerites brown. Penial bridge [fused with gonovectes - see Rhithrocloeon/fg1 (1)] has madian projection in a form of rather long angulate trapeze with a shorter finger-like median process (Figs 12, 15, 17, 18). Male subimago has trapezoid portion as long as in imago and finger-like process thicker than in imago; most part of subimaginal penis colorless and membranose, hemispheric apex of median projection brown and sclerotized (Figs 14, 16).

Imago, female. Head, thorax and abdomen entirely brown. On fore leg $1^{\text {st }}$ and $2^{\text {nd }}$ tarsomeres have no apical thorns, only $3^{\text {rd }}$ tarsomere has apical thorn. On middle and hind legs $1^{\text {st }}+2^{\text {nd }}$ tarsomere has no apical thorn, only $3^{\text {rd }}$ tarsomere has apical thorn as in male.

Egg. Oval, surface without regular relief.

DIMENSION. Fore wing length 4-6 mm.

\subsection{2-2. Kivuiops/g(1) elouardi [Rhithrocloeon]}

Systematic position: Rhithrocloeon/fg1-Rhithrocloeon/fg2Kivuiops/g(1).

Original binomen: Rhithrocloeon elouardi Gillies, 1989.

Possible binomina:

- Rhithrocloeon (Kivuiops) elouardi;

- Kivuiops elouardi.

REFERENCES. Rhithrocloeon elouardi: Gillies, 1989 (male imago). Kivua elouardi: Lugo-Ortiz \& McCafferty, 1996; Gattolliat, 2006 (male imago). Kivuiops elouardi: Lugo-Ortiz \& McCafferty, 2007. Novokivua elouardi: Özdikmen, 2008.
Described as male imagoes from Côte d'Ivoire [Gillies, 1989; Gattolliat, 2006]. Tarsus of middle and hind leg has a single thorn on $3^{\text {rd }}$ segment only (as in Fig. 4) (Gattolliat, personal communication). Larvae unknown.

\subsection{2-3. Kivuiops/g(1) munyagae sp.n. \\ [Rhithrocloeon]}

Figs 19-23.

Systematic position: Rhithrocloeon/fg1—Rhithrocloeon/fg2Kivuiops/g(1).

Original binomen: Rhithrocloeon (Kivuipos) munyagae Kluge, sp.n.

Possible binomina:

- Rhithrocloeon (Kivuiops) munyagae;

- Kivuiops munyagae.

MATERIAL. Holotype: L-S/IO $\sigma^{r}\{$ No. [XIV] (2)\}, UGANDA: Kanungu district, river Munyaga below Bwindi national park, 24.VII.2007, coll. N. Kluge. Paratypes: the same locality, 2125.VII.2007, coll. N. Kluge: $2 \mathrm{~L} / \mathrm{SO} 0^{7}, 2 \mathrm{~L} / \mathrm{S}$, 12 larvae.

Larva. Structure is the same, as in insuetum [Cloeon] (see above), incuding presence of dark stout pointed denticles at median part of posterior margin of metanotum (Fig. 23). Spine-like setae on outer margin of tibia variable: either numerous and occypy the whole length of tibia (as in insuetum [Cloeon] - Figs 5-6), or few an locate only in distal part of tibia (as in elgonensis [Rhithrocloeon]).

Subimago. Cuticular coloration, hypodermal coloration and texture as in insuetum [Cloeon] (see above). About genital structure - see characteristics of male imago.

Imago, male. Coloration as in insuetum [Cloeon] (see above). Fore wing widest in proximal part (Fig. 21). On middle and hind legs $1^{\text {st }}+2^{\text {nd }}$ tarsomere has no apical thorn, only $3^{\text {rd }}$ tarsomere has apical thorn (as in Fig. 4). Penis brown; penial bridge [fused with gonovectes - see Rhithrocloeon/ fgl (1)] has madian projection in a form of very short angulate trapeze with a longer finger-like median process

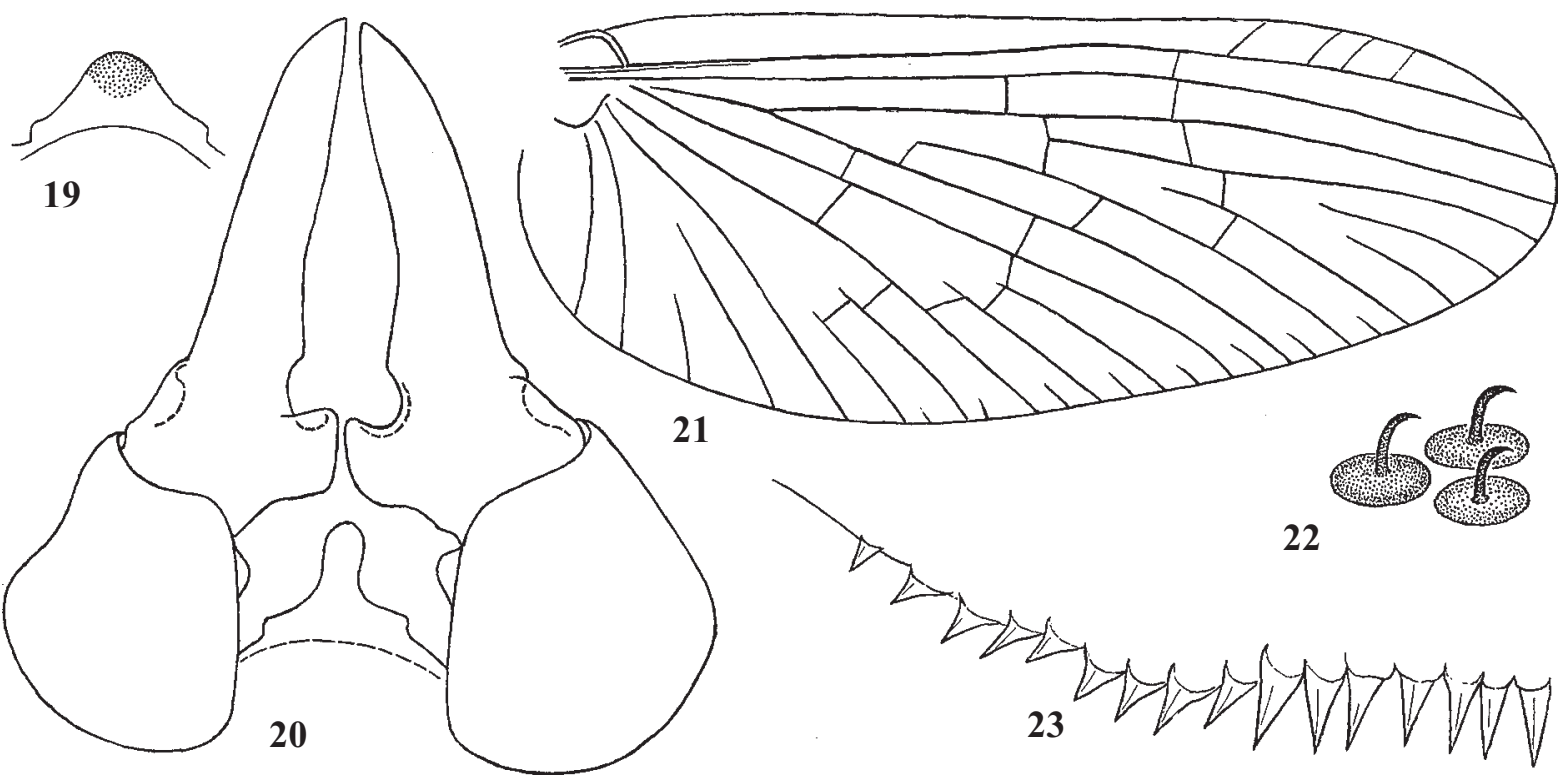

Figs 19-23. Rhithrocloeon/fg2-Kivuiops/g1 munyagae sp.n. [Rhithrocloeon]: 19 — penis of subimago, extracted from mature larva; 20 genitals of male imago (as visible through subimaginal cuticle); 21 - shape and venation of fore wing; 22 - microtrichia on subimaginal wing; 23 - left half of median part of hind margin of larval metanotum (the same scale as in Fig 25); 20-21 — holotypus.

Рис. 19-23. Rhithrocloeon/fg2-Kivuiops/g1 munyagae sp.n. [Rhithrocloeon]: 19 - пенис субимаго, отпрепарированный из зрелой личинки; 20 - гениталии самца имаго (видимые сквозь субимагинальную кутикулу); 21 — форма и жилкование переднего крыла. 22 - микротрихии на крыле субимаго; 23 - левая половина медиальной части заднего края метанотума личинки (то же увеличение, что на рис. 25); 20-21 - голотип. 
(Fig. 20). Male subimago has trapezoid portion as short as in imago; instead of the finger-like process it has a wider and shorter protuberance; most part of subimaginal penis colorless and membranose, hemispheric apex of median projection brown and sclerotized (Fig. 19).
Female, imago. Judging by subimaginal tarsi, visible in mature larva, on fore leg $1^{\text {st }}$ and $2^{\text {nd }}$ tarsomeres have no apical thorns, only $3^{\text {rd }}$ tarsomere has apical thorn; on middle and hind legs $1^{\text {st }}+2^{\text {nd }}$ tarsomere has no apical thorn, only $3^{\text {rd }}$ tarsomere has apical thorn, as in male (as in Fig. 4).

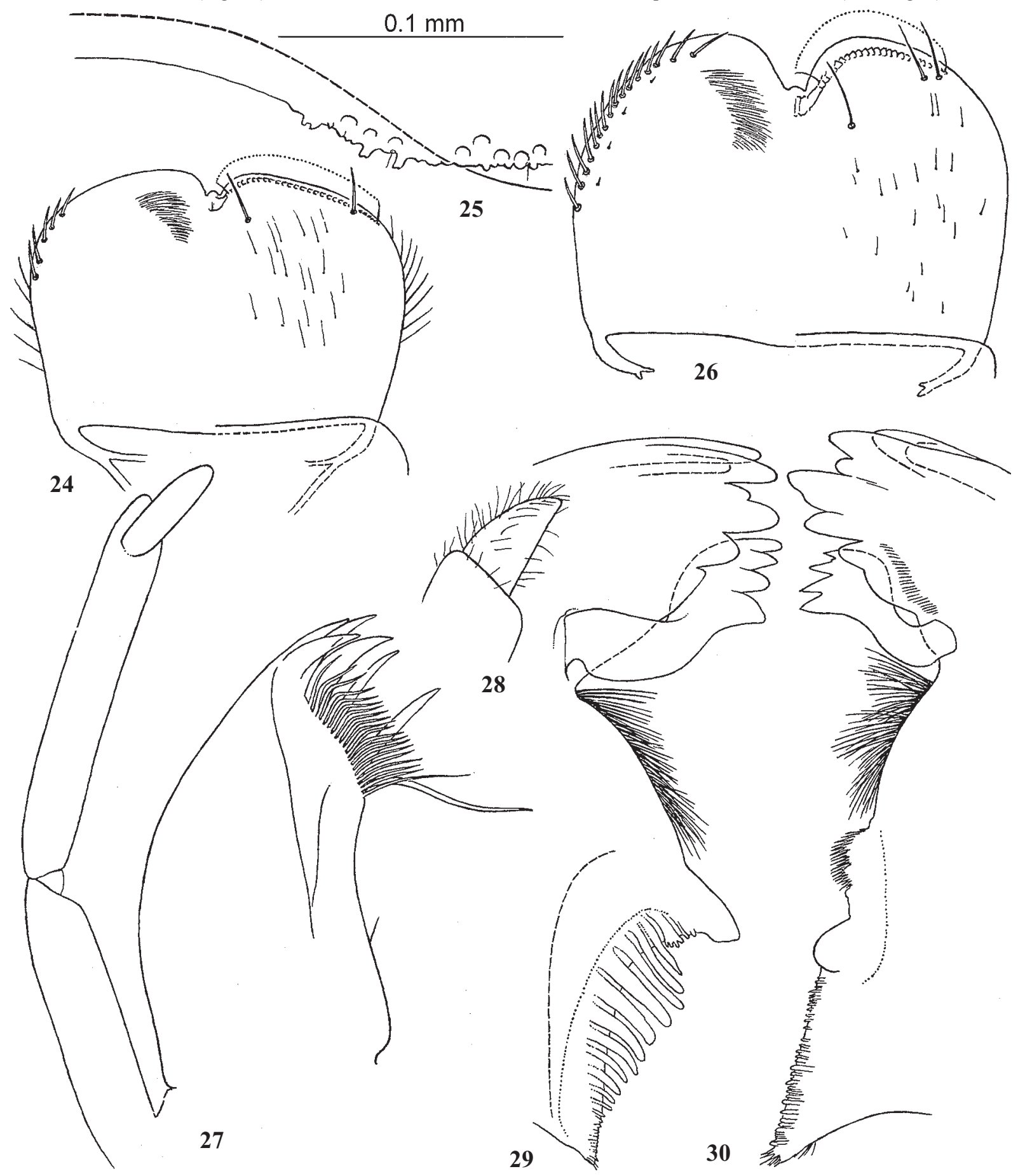

Figs 24-30. 24 - Rhithrocloeon/fg3 sp.1, labrum (in left - ventral view, in right - dorsal view); 25-30 - larva of Rhithrocloeon/ fg2-Kivuiops/g1 elgonensis sp.n. [Rhithrocloeon]; 25 - left half of median part of hind margin of metanotum and fore margin of first abdominal tergum; 26 - labrum (in left — ventral view, in right — dorsal view); 27 - maxilla, ventral view; 28 - third segment of maxillary palp; 29-30 - left and right mandibles (26-27 - holotypus).

Рис. 24-30. 24 - Rhithrocloeon/fg3 sp.1, верхняя губа (слева вентрально, справа дорсально); 25-30 — Rhithrocloeon/fg2Kivuiops/g1 elgonensis sp.n. [Rhithrocloeon]; 25 - левая половина медиальной части заднего края метанотума личинки и переднего края первого тергита брюшка; 26 - верхняя губа (слева вентрально, справа дорсально); 27 — максилла, вентрально; 28 - третий членик максиллярного щупика; 29-30 - левая и правая мандибулы (26-27 - голотип). 
Egg. Oval, surface without regular relief.

DIMENSION. Fore wing length $4.5 \mathrm{~mm}$.

COMPARESON. By genital structure the East-African species munyagae sp.n. [Rhithrocloeon] is similar to the West-African species elouardi [Rhithrocloeon]; differs by shape of fore wing, which in mynyagae sp.n. [Rhithrocloeon] is widest in proximal part (Fig. 21), and in elouardi [Rhithrocloeon] is widest in distal part [Gillies, 1989: Fig. 1; Gattolliat, 2006: Fig.20].

\subsection{2-4. Kivuiops/g(1) elgonensis sp.n. [Rhithrocloeon]}

Figs 25-36.

Systematic position: Rhithrocloeon/fg1—Rhithrocloeon/fg2Kivuiops/g(1).

Original binomen: Rhithrocloeon (Kivuipos) elgonensis Kluge, sp.n.

Possible binomina:

- Rhithrocloeon (Kivuiops) elgonensis;

- Kivuiops elgonensis.

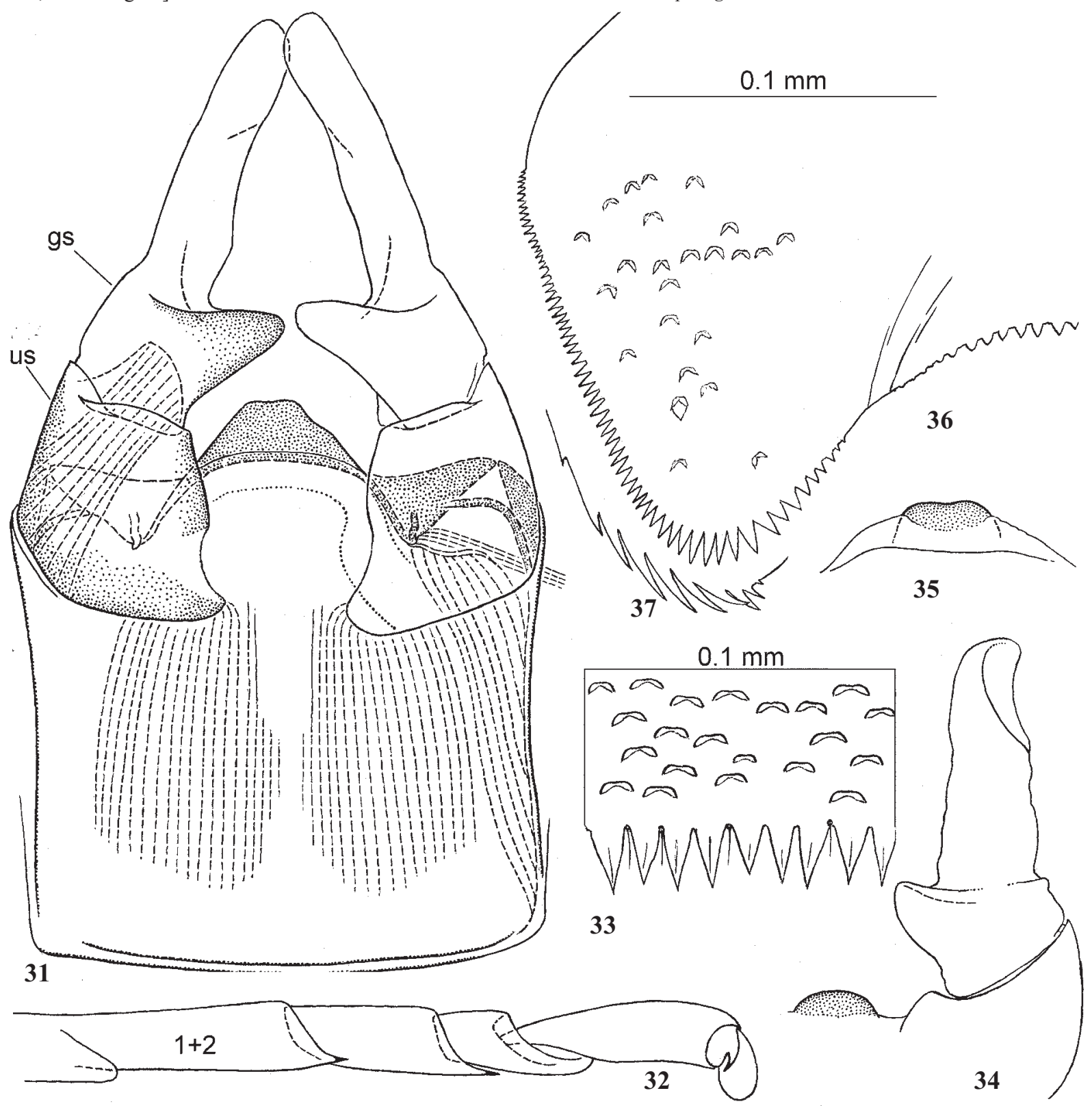

Figs 31-37. Rhithrocloeon/fg2: 31-36 - Rhithrocloeon/fg2-Kivuiops/g1 elgonensis sp.n. [Rhithrocloeon]; 31 - genitals of male imago, ventral view (sterno-styligeral muscles, left gonostylar muscle and right penial muscles shown by interrupted lines; gonoducts shown by dotted lines); 32 - tarsus of imaginal middle leg; 33 - hind margin of larval andominal tergum IX; 34 - subimaginal exuviae of penis and right unistyliger with gonostylus; 35 - penis of subiago, extracted from mature larva; 36 - larval paraproct (31-34, 36 - holotypus); 37 - Rhithrocloeon/fg3 sp.2, distal margin of larval paraproct; gs - gonostylus; us - unistyliger; $1+2$ - fused $1^{\text {st }}$ and $2^{\text {nd }}$ tarsomeres.

Рис. 31-37. Rhithrocloeon/fg2: 31-36 - Rhithrocloeon/fg2-Kivuiops/g1 elgonensis sp.n. [Rhithrocloeon]; 31 - гениталии самца имаго, вентрально (стерно-стилигеральная мышца, левая гоностилярная мышца и правые мышцы пениса показаны прерывистыми линиями; гонодукты показаны пунктиром); 32 - лапка средней ноги имаго; 33 - задний край IX тергита брюшка личинки; 34 субимагинальный экзувий пениса и правого унистилигера с гоностилем; 35 - пенис субимаго, отпрепарированный из зрелой личинки; 36 - парапрокт личинки (31-34, 36 - голотип); 37 — Rhithrocloeon/fg3 sp.2, дистальный край парапрокта личинки; gs — гоностиль; us - унистилигер; $1+2$ - слитые 1-й и 2-й тарсомеры. 
MATERIAL. Holotype: L-S-IO' \{No. [XLII] (11)\}, UGANDA, Kapchorwa district, mount Elgon, Sipi Falls, 27.VIII.2007, coll. N Kluge. Paratypes: the same locality, 25-31.VIII.2007: 2 L/S $\sigma^{7}, 3$ L/ $\mathrm{S}_{+}, 8$ larvae.

Larva. Structure is the same, as in insuetum [Cloeon] (see above), with the following differences: (1) Posterior margin of metanotum in median part bears a few irregular small denticles (Fig. 25), which are not larger than vestigial denticles of $1^{\text {st }}$ abdominal tergum. (2) Spine-like setae on outer margin of each tibia are few, occupy only its distal part, sometimes restricted to extreme end of tibia.

Subimago. Cuticular coloration, hypodermal coloration and texture as in insuetum [Cloeon] (see above). About genital structure - see characteristics of male imago.

Imago, male. Coloration as in insuetum [Cloeon] (see above). Fore wing widest in proximal part (as in Fig. 21). On middle and hind legs $1^{\text {st }}+2^{\text {nd }}$ tarsomere has apical thorn, as well as $3^{\text {rd }}$ tarsomere; thus, tarsus has 2 apical thorns (Fig. 32). Penis brown; penial bridge [fused with gonovectes - see Rhithrocloeon/fg1 (1)] has median projection in a form of trapeze evenly narrowing toward apex (Fig. 31). Male subimago has penis colorless and membranose, with apex brown and sclerotized, as wide as apex of imaginal median projection (Fig. 34, 35).

Imago, female. Judging by subimaginal tarsi, visible in mature larva, on fore leg $2^{\text {nd }}$ tarsomere has apical thorn, as well as $3^{\text {rd }}$ tarsomere; on middle and hind legs $1^{\text {st }}+2^{\text {nd }}$ tarsomere has apical thorn, as well as $3^{\text {rd }}$ tarsomere (as in male - Fig. 32); thus, each tarsus has 2 apical thorns.

Egg. Oval, surface without regular relief.

DIMENSION. Fore wing length $5 \mathrm{~mm}$.

COMPARESON. Adults (imago and subimago) of both sexes differ from all other three species of Kivuiops (insuetum [Cloeon], elouardi [Rhithrocloeon] and munyagae [Rhithrocloeon]) by presence of apical thorn on $1^{\text {st }}+2^{\text {nd }}$ tarsomere. Male imago well differs from all other three species of Kivuiops by absence of finger-like process on median penial projection. Larva differs at least from insuetum [Cloeon] and munyagae [Rhithrocloeon] by absence of long denticles on metanotum and by less numerous spine-like setae on outer side of tibia. Mature larva, which has subimaginal parts developed under cuticle, can be determined by presence of apical thorn on $1^{\text {st }}+2^{\text {nd }}$ tarsomere.

\subsection{Plesiomorphon Bugilliesia/g(1), or Bugilliesia Figs 38-46.}

Systematic position: pm.Protopatellata-Rhithrocloeon/fg1pm.Bugilliesia/g(1).

Hierarchical typified name: Bugilliesia/g1 [g: Bugilliesia LugoOrtiz \& McCafferty, 1996: 184, type species Afroptilum guineense Gillies, 1990 (design. orig.)].

Possible rank-based names:

— gen. Bugilliesia;

- subgen. Bugilliesia in gen. Rhithrocloeon s.1.

In circumscription fits:

- group sudanense: Gillies, 1990.

- gen. Bugilliesia: Lugo-Ortiz \& McCafferty, 1996.

Characters of unclear phylogenetic status.

(1) In species, whose larvae are known, labrum lacks a pair of submedian setae, and latero-distal setae form rather long rows. The same in some other Turbanoculata.

\section{Plesiomorphies.}

(2) Hind wings developed, of «Centroptilum-type» [see Rhithrocloeon/fg1 (6)].

(3) Larval claw [slender - see Rhithrocloeon/fg1 (4)] retains both rows of denticles.

(4) Unlike Kivuiops, maxilla [of «Cloeon-type» — see Rhithrocloeon/fg1 (3)] retains more than one seta in innerdorsal row.
Composition. 7 species belong here for certain, being known as male imagoes, which have characteristic genital structure [see Rhithrocloeon/fg1 (1.1)] and hind wings; these are: biloba Gattolliat, 2006 [Bugilliesia] (see below); cavalliensis Gattolliat, 2006 [Bugilliesia]; griseum Gillies, 1990 [Afroptilum (Afroptilum)] (see below); guineense Gillies, 1990 [Afroptilum (Afroptilum)]; notabile Kimmins, 1956 [Centroptilum] (see below); sudanense Ulmer, 1916 [Centroptilum] (see below); truncata Gattolliat, 2006 [Bugilliesia]. Among them, larvae associated with imago by rearing, are known for griseum [Afroptilum], guineense [Afroptilum] and sudanense [Centroptilum] [Gillies, 1990].

Gillies [1990] attributed to the "Afroptilum sudanense group" also nitidum Ulmer, 1916 [Centroptilum] (= nigroalbum Navas, 1932 [Cloeon]; = bredoanum Navas, 1933 [Cloeon]), known as adults. Later this species, together with other species of the sudanense group, was moved to the genus Bugilliesia [Lugo-Ortiz \& McCafferty, 1996]. Genitals of nitidum [Centroptilum] are unknown [Demoulin, 1957], so there is no reason to place it to Bugilliesia. Structure of its female fore tibia have not been described, so it is unclear if it belongs to Protopatellata or Anteropatellata. This species should be regarded as Turbanoculata incertae sedis.

Gattolliat and Barber-James described margaretae Gattolliat \& Barber-James, 2009 [Bugilliesia] and attributed mirandei Lugo-Ortiz \& McCafferty, 1997 [Cheleocloeon] to the genus Bugilliesia. Both species are described as larvae only; possibly they are conspecific with some species described as imagoes [Gattolliat et al., 2009].

\section{2-1. Bugilliesia/g(1) sp.N Figs 40-44.}

Systematic position: Rhithrocloeon/fg1-pm.Bugilliesia/g(1).

MATERIAL. UGANDA, Jinja, F.I.R.R.I., 6-10.VII.2007 (at light), coll. N. Kluge: 5 IO', 10 I우 Bujagali Falls 6.VII.2007 (at light), coll. N. Kluge: 1 S-IO'

Imago, male. Head and thorax pale ocher. Turban eyes orange. Legs pale ocher, only rotating sclerite on apex of fore tibia brownish. Fore wing colorless, veins light, only basal parts of Sc and RA brown (Fig. 44). Hind wing as in Fig. 43. Abdomen colorless with darkened lateral tracheal trunks. Genitals entirely colorless. Penial bridge fused with unistyligers, its median part with gonopore turned ventrally (Figs 40-42). Cerci colorless. Fotre wing lenght $5.5 \mathrm{~mm}$.

\section{2-2. Bugilliesia/g(1) sp.K}

Systematic position: Rhithrocloeon/fg1—pm.Bugilliesia/g(1). MATERIAL. Brit. East Africa, Kahavati, 20.I.1911, coll. Svatosh: $1 \mathrm{IO}^{\text {'. }}$

Imago, male. Fore wings with basal parts of Sc and RA brown, crossveins bordered by brown. Hind wing very narrow, with one longitudinal vein, costal brocess hooked. Proximal widening of styliger with additional lateral projection. Penial bridge with long and thin median projection. Fore wing length $8 \mathrm{~mm}$.

\section{2-3. Bugilliesia/g(1) biloba [Bugilliesia]}

\section{Fig. 45}

Systematic position: Rhithrocloeon/fg1-pm.Bugilliesia/g(1).

Original binomen: Bugilliesia biloba Gattolliat, 2006.

Possible binomina:

- Rhithrocloeon (Bugilliesia) biloba;

- Bugilliesia biloba.

REFERENCES. Bugilliesia biloba Gattolliat, 2006 (male and female imago).

MATERIAL. MALI, Bafing bei Tinko, 1.X.1991, coll. D. Tobias: IO'. 


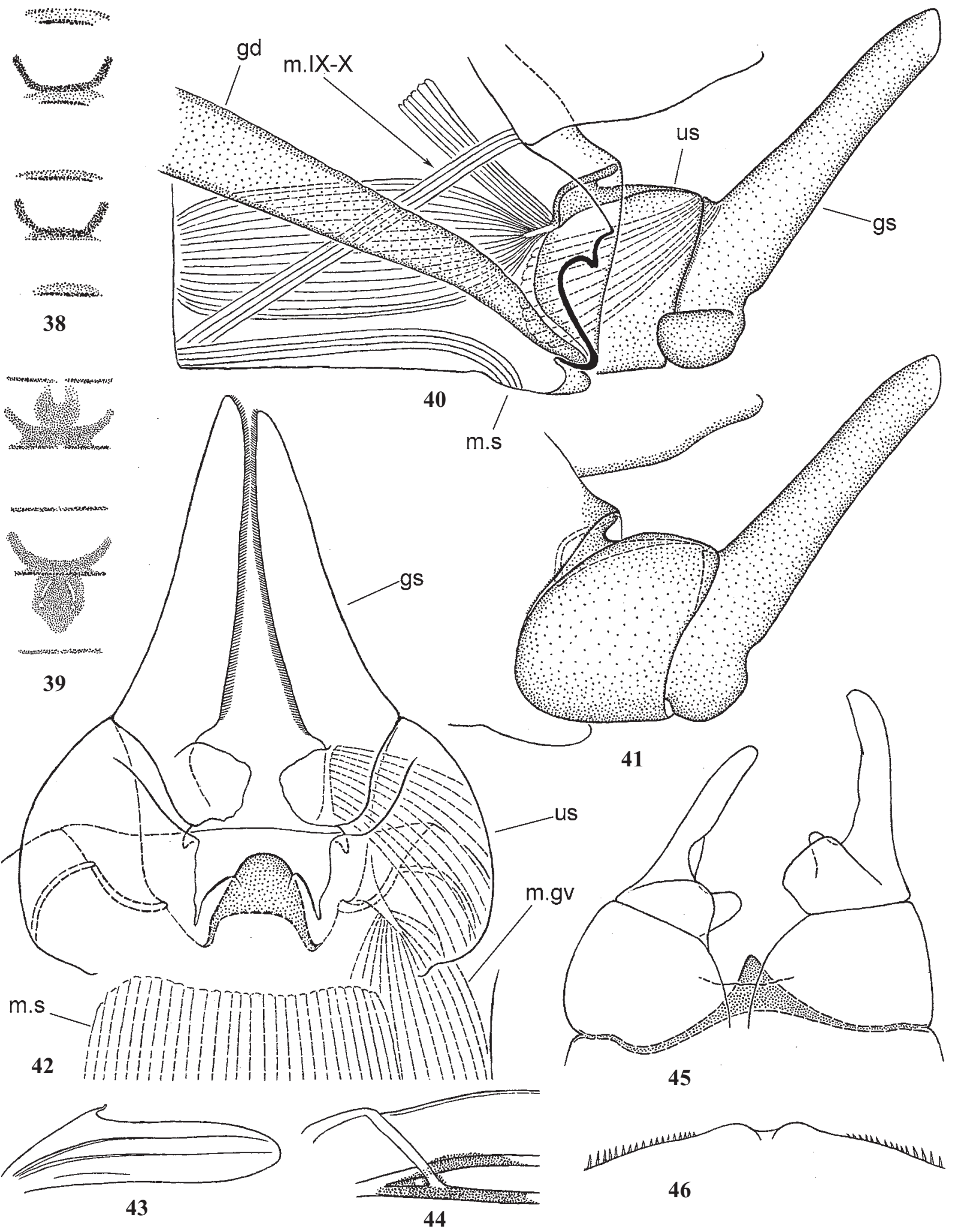

Figs 38-46. Rhithrocloeon/fg1-Bugilliesia/g(1): 38-39 - notabile [Centroptilum], color pattern of III-VI abdominal terga of winged male and female; 40-44 - sp.N; 40 - genitals of male imago, medan section; 41 - the same, lateral view; 42 - the same, ventral view (sterno-styligeral muscle, left gonostylar muscle and left penial muscle shown by interrupted lines); 43 — hind wing; 44 — brown pigmentation at base of fore wing; 45 - biloba [Bugilliesia], genitals of male imago (ventral view); 46 - sudanense [Centroptilum], posterior margin of IX abdominal sternum (protogonostyli) of mature male larva; gd — gonoduct; gs — gonostylus; m.gv — muscle of gonovectis; m.s — median sterno-styligeral muscle; m.IX-X — intersegmental ventral muscle; us — unistyliger. 


\section{2-4. Bugilliesia/g(1) notabile [Centroptilum]} Figs 38, 39.

Systematic position: Rhithrocloeon/fg1—pm.Bugilliesia/g(1) Original binomen: Centropotilum notabile Kimmins, 1956. Possible binomina:

- Rhithrocloeon (Bugilliesia) notabile;

- Bugilliesia notabile.

REFERENCES. Centropotilum notabile Kimmins, 1956 (male and female imago); Afroptilum (Afroptilum) notabile: Gillies, 1990; Bugilliesia notabilis: Lugo-Ortiz \& McCafferty, 1996; Gattoliatt, 2006 (in key to male imagoes).

MATERIAL. UGANDA, Jinja, F.I.R.R.I., 6-10.VII.2007 (at light), coll. N. Kluge: 8 I+; Bujagali Falls 6.VII.2007 (at light), coll N. Kluge: $1 \mathrm{~S} \sigma^{\top}, 12 \mathrm{I}$ \%

Adults have characteristic color pattern on abdominal terga (Figs 38-39). Larvae unknown.

\section{2-5. Bugilliesia/g(1) sudanense [Centroptilum]} Fig. 46.

Systematic position: Rhithrocloeon/fg1—pm.Bugilliesia/g(1). Original binomen: Centroptilum sudanense Ulmer, 1916.

Possible binomina:

- Rhithrocloeon (Bugilliesia) sudanense;

- Bugilliesia sudanense.

REFERENCES. Centroptilum sudanense Ulmer, 1916 (male imago); Kimmins, 1956 (male imago). Afroptilum (Afroptilum) sudanense: Gillies, 1990 (larva). Bugilliesia sudanense: Lugo-Ortiz \& McCafferty, 1996; Gattolliat, 2006 (in key for male imago).

MATERIAL. SUDAN, White Nile, 26.I.1964, coll. A.V. Monakov: 4 larvae. Ed-Dueim, 19.XI.1963, coll. A.V. Monakov: 1 male larva.

Larval structure agrees with the description by Gillies [1990].

\section{2-6. Bugilliesia/g(1) griseum [Afroptilum]}

Systematic position: Rhithrocloeon/fg1—pm.Bugilliesia/g(1). Original binomen: Agfroptilum griseum Gillies, 1990.

Possible binomina:

- Rhithrocloeon (Bugilliesia) griseum;

- Bugilliesia grisea.

REFERENCES. Afroptilum (Afroptilum) griseum Gillies, 1990 (reared male and female imagoes and larvae).; Gillies, 1997 (tergalii mobility). Bugilliesia grisea: Lugo-Ortiz \& McCafferty, 1996; Gattolliat, 2006.

MATERIAL. UGANDA: river Victoria Nile at Bujagali Falls, 7.VII.2007, coll. N. Kluge: 1 larva; Kasese district, river Nyamagasan near Kiburara, 8-13.VIII.2007, 1 larva.

ACKNOWLEDGEMENT. This investigation was supported by the Russian Federal Program for Support Leading Scientific Schools, grant No. 332.2010.4.

\section{References}

Demoulin G. 1957. Revision de quelques Éphéméroptères décrits du Congo belge par L. Navás. III // Bulletin et Annales de la Société Entomologique de Belgique. T.93. No.9-10. P.257-275.

Gillies M.T. 1985. A preliminary account of the East African species of Cloeon Leach and Rhithrocloeon gen.n. (Ephemeroptera) // Aquatic Insects. Vol.7. No.1. P.1-17.

Gillies M.T. 1988. Descriptions of the nymphs of some Afrotropical Baetidae (Ephemeroptera). I. Cloeon Leach and Rhithrocloeon Gillies // Aquatic Insects. Vol.10. No.1. P.49-59.
Gillies M.T. 1989. Occurrence of Rhithrocloeon (Baetidae: Ephemeroptera) in West Africa // Revue d'Hydrobiologie Tropicale. Vol.22. P.287-288.

Gillies M.T. 1990. A revision of the African species of Centroptilum Eaton (Baetidae, Ephemeroptera) // Aquatic Insects. Vol.12 No.2. P.97-128.

Gillies M.T. 1997. Gill mobility in the Baetidae (Ephemeroptera): Results of a short study in Africa // P. Landolt \& M. Sartori Sartori (eds). Ephemeroptera \& Plecoptera. Biology-EcologySystematics. (Proc. 8th Int. Conf. Ephemeroptera \& 12th Int. Symp. Plecoptera, 14-20 August 1995, Losanne, Switzerland). Mauron+Tinguely \& Lacht SA, Fribourg / Switzerland P.113116.

Gillies M.T. 2001. New species of Baetidae (Ephemeroptera) from the Upper River Sigi, Usambara, Tanzania // Journal of Natural History. Vol.35. P.23-32.

Gillies M.T. \& Elouard J.-M. 1990. The mayfly-mussel association, a new example from the river Niger basin // J.C. Campbell (ed.). Mayflies and Stoneflies (Proc. 5th Int. Conf. Ephemeroptera \& 9th Int. Symp. Plecoptera 18-24 February 1987, Marysville, Australia). Kluwer Acad. Publ. P.289-297.

Gattolliat J.-L. 2003. The genera Demoulinia Gillies and Potamocloeon Gillies (Ephemeroptera: Baetidae) in Madagascar // Zootaxa. No.184: 1-18

Gattolliat J.-L. 2006. Bugilliesia Lugo-Ortiz and McCafferty and allied genera (Baetidae, Ephemeroptera), with emphasis on West African fauna // Mittelungen der Schweizerischen Entomologischen Gesellschaft. Vol.79. P.81-298.

Gattolliat J.L., Barber-James H.M. \& Monaghan M.T. 2009. New species and generic delimitation of the Afrotropical genera Bugilliesia Lugo-Ortiz \& McCafferty, 1996; Cheleocloeon Wuillot \& Gillies, 1993 and Delouardus Lugo-Ortiz \& McCafferty, 1999 (Ephemeroptera: Baetidae) // Aquatic Insects. Vol.31. No.3. P.167-186.

Gattolliat J.-L. \& Monaghan M.T. 2010. DNA-based association of adults and larvae in Baetidae (Ephemeroptera) with the description of a new genus Adnoptilum in Madagascar // Journal of the North American Benthological Society. Vol.29 No.3. P.10421057

Kimmins D.E. 1956. New species of Ephemeroptera from Uganda // Bulletin of the British Museum (Natural History), Entomology. Vol.4. No.2. P.69-87.

Kluge N.J. 2004. The phylogenetic system of Ephemeroptera. Kluwer Academic Publishers. 456 p.

Kluge N.J. 2011. Non-African representatives of the plesiomorphion Protopatellata (Ephemeroptera: Baetidae) // Russian Entomological Journal. Vol.20. No.4. P.361-376.

Kluge N.J. 2012. [Cladoendesis and a new look to evolution of insect metamorphosis] // [Entomologicheskoe Obozrenie]. Vol.91. No.1. P.63-78.

Kluge N.J. \& Novikova E.A. 2011. Systematics of the mayfly taxon Acentrella (Ephemeroptera, Baetidae), with description of new Asian and African species // Russian Entomological Journal. Vol.20. No.1. P.1-56.

Kopelke J.-P. 1980. Morphologische Studien an den Eiern der Eintagsfliegen (Ephemeroptera) aus der Emergenz des zentralafrikanischen Bergbaches Kalengo // Mitteilungen der Schweizerischen Entomologischen Gesellschaft. Vol.53. No.2-3.P.297311.

Lugo-Ortiz C.R. \& McCafferty W.P. 1996. The Bugelliesia complex of African Baetidae (Ephemeroptera) // Transactions of the American Entomological Society. Vol.122. No.4. P.175-197.

Lugo-Ortiz C.R. \& McCafferty W.P. 2007. Kivuiops: a new name for a generic homonym of Afrotropical Baetidae (Ephemeroptera) //

Рис. 38-46. Rhithrocloeon/fg1-Bugilliesia/g(1): 38-39 - notabile [Centroptilum], окраска III-VI тергитов брюшка крылатых самца и самки; 40-44 - sp.N; 40 - гениталии самца имаго, медиальный срез; 41 - то же, латерально; 42 - то же, вентрально (стерностилигеральная мышца, левая гоностилярная мышца и левая мышца пениса показаны прерывистыми линиями); 43 - заднее крыло; 44 - бурая пигментация в основании переднего крыла; 45 - biloba [Bugilliesia], гениталии самца имаго (вентрально); 46 - sudanense [Centroptilum], задний край IX стернита брюшка (протогоностили) зрелой личинки самца; gd — гонодукт; gs — гоностиль; m.gv — мышца гоновектиса; m.s — медиальная стерно-стилигеральная мышца; m.IX-X — межсегментарная вентральная мышца; us - унистилигер. 
Proceedings of the Entomological Society of Washington. Vol.109. No.3. P.738.

Özdikmen H. 2008. Replacement names for three preoccupied mayflies genus group names (Ephemeroptera) // Munis Entomology \& Zoology. Vol.3. No.2. P.651-653.

Ulmer G. 1916. Ephemeropteren von Äquatorial-Afrika // Archiv für Naturgeschichte (A) (1915). Bd.81. Nr.7. S.1-19. 